\title{
特集に寄せて
}

\author{
常任理事・カーエレクトロニクス研究会主査 三宅 敏広*
}

\section{Introduction to the Special Edition}

Toshihiro MIYAKE**

\footnotetext{
* 株式会社デンソー基盤ハードウェア開発部（４448-8661 愛知県刈谷市昭和町 1-1）

* Basis Electronics R \& D Division, DENSO CORPORATION (1-1 Showacho, Kariya, Aichi 448-8661)
}

自動車の電子制御は, ガソリンエンジンの制御から始ま り, 現在では, 走る, 曲がる, 止まるという自動車の機能 の多くが電子制御されるようになってきている。さらに今 後の自動車に期待される進化は, 安全, 快適, 低環境負荷 というベクトルを持ち, 車両の外側との情報通信, 車両制 御の高機能化・高精度化など, カーエレクトロニクスの多 様化, 高機能化が益々求められるようになってきている。 このような方向性の中で, 自動車用制御システムの実装技 術に対しては，(1)システム化（ECU 統合によるシンプル 化\&高機能化）に対応する, 小型, 高耐熱, 高耐振実装技 術, (2)電動化（制御の高機能・高性能化）に対応する, ア クチュエータ一体・大電流対応実装技術などの飛躍的技術 革新が求められている。さらに, (3)電子化・無線化（車両 内外の情報通信）に対応する, 入出力機器, $\mathrm{EMC}$ 技術など も増々重要となってきている。

今回の全冊特集では, カーエレクトロニクスをその黎明 期から振り返り, どのような発展をたどって現在に至り, さらに今後はどこに向かおうとしているのかについての全 体像を示すことで, 車載システムの全体動向を俯瞰する視 点から今後必要となる車載制御機器の実装技術を広く捉え ることを重点の 1 つとし, カーエレクトロニクス全体を俯 瞰しながら実装技術の着眼点も含めた基調論文を MTEC (元 デンソー専務取締役) の加藤光治氏に御執筆いただい た。

続いて全体俯瞰の視点から今後必要となる車載制御機器 の実装技術について，技術分野を大きく 3 つに分けて（1. プリント配線板・電子部品, 2. メカトロニクス・パワーエ レクトロニクス, および 3 . 電磁界インターフェース・設 計 $\mathrm{CAE}$ ), 幅広く最新動向をピックアップして概観するこ とをもう一つの重点とした。

「1. プリント配線板・電子部品」分野においては, 大電 流に対応するプリント配線板などの動向について日本シイ エムケイの小林裕二氏, メイコーの戸田光昭氏に解説いた だき, また, 電子部品の動向については, KOAの赤羽秀樹 氏, 出雲村田製作所の竹内嘉夫氏に解説いただいた。「2. メカトロニクス・パワーエレクトロニクス」分野において
は, 電動コンポーネント技術について日立製作所の難波明 博氏に, コンポーネント間などの接続用コネクタについて イリソ電子工業の山口富三郎氏にそれぞれ解説いただい た。また，パワーエレクトロニクスの切り口では，パワー デバイスの動向についてデンソーの神谷有弘氏に，パワー デバイスの放熱技術については, 大同大学の山田 靖氏, デンソーの篠田卓也氏に解説いただいた。「3. 電磁界イン ターフェース・設計 $\mathrm{CAE} 」$ 分野においては, アンテナから ワイヤレス電力伝送, 人体通信までの電磁界インター フェースについて東京工芸大学の越地福朗氏に概説いただ き, 電力伝送の事例を中心に豊田中央研究所の服部佳晋氏 に，また人体通信技術については，資生堂の加藤康男氏に それぞれ解説いただいた。さらに，設計 CAE 分野では，信 号や電源の品質, 電磁特性を中心としたシミュレーション 技術について静岡大学の浅井秀樹氏に解説いただいた。

今後, 安全, 快適, 低環境負荷の方向に向かって自動車 が進化していくためにも，その制御システムのハードウェ ア全体を成立させる必須技術として，実装技術の役割は 増々大きくなってきている。これまで, “車載実装”と言え ばプリント配線板上の高信頼性部品実装やパワーデバイス 実装がクローズアップされることが多かったが, 電動化・ 電子化・無線化の方向性の中で, アクチュエータ, セン サ, 電磁界インターフェースなどを含めたハードウェア構 成要素全体をどのように実装するかということが今後の “車載実装”の重要な課題と考えられる。

最後に，お忙しい中，御執筆を引き受けていただきまし た著者の皆様, 今回の特集の企画, 編集に隽わっていただ きました関係者の方々に深く感謝いたします。

(2016.6.6- 受理)

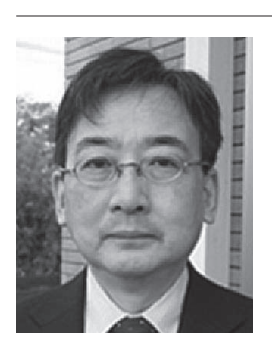

著者紹介

三宅敏広（みやけ としひろ）

1985 年岐阜大学大学院工学研究科修士課程修了. 1991 年株式会社デンソー入社, プリント配線板扔 よび接続技術開発に従事，2009 年岐阜大学大学院 工学研究科博士後期課程物質工学専攻修了, 博士 (工学), 現在 基盤ハードウェア開発部にて 車載メカトロニクス実装技術開発に従事, JIEP 常任理事, カーエレクトロニクス研究会主查。 